\title{
Teorias e discursos transgressivos
}

\section{Théories et discours transgressifs}

\section{Ida Lucia Machado Universidade Federal de Minas Gerais - UFMG}

\section{Résumé}

Cet article aura pour base le thème "transgressions" discursives que nous approcherons, grosso modo, à partir de deux axes: (i) de prime abord, nous considérerons comme «élément transgressif» l'instrumental d'analyse que sera ici appliqué; (ii) ensuite, liée à la première, nous examinerons une autre forme de transgression - la générique. Pour ce faire nous montrerons un panorama de la théorie de l'analyse du discours depuis ces débuts jusqu'à la création de la théorie Sémiolinguistique, en soulignant les spécificités de l'Analyse du Discours dans l'univers de la Linguistique; en guise d'illustration nous ferons une analyse de deux petits poèmes que nous appelerons «transgressifs», puisqu'un mélange de genres semble s'y opérer. Bref, tout au long de cet article nous avons été guidés par deux questions: (i) dans le domaine de la Linguistique, l'Analyse du Discours est-elle transgressive? (ii) dans le domaine de la transgression générique devons-nous considérer qu'un mélange de genres a vraiment eu lieu ou plutôt sommes-nous devant une action (ludique et subversive) qui montre que les effets d'un genre donné peuvent être réappropriés ou insérés dans un autre genre, différent du premier?

\section{Mots-clés}

Sémiolinguistique, Transgression générique, Effets de genre, Ffaits divers. 


\section{Resumo}

Nosso artigo tem por base o tema «transgressões» discursivas que será abordado a partir de dois pontos: (i) em primeiro lugar, consideraremos como "elemento transgressivo" o instrumental de análise que será aqui aplicado, ou seja, a própria análise do discurso; (ii) em segundo lugar, examinaremos uma outra forma de transgressão (ligada à primeira), ou seja, a transgressão genérica. Assim, ainda que de forma panorâmica, iremos percorrer parte do caminho que passa pelos primórdios da teoria da análise do discurso (na França) até os dias de hoje; esse percurso dará uma especial ênfase à Teoria Semiolingüística, criada por Patrick Charaudeau. Para ilustrar o que foi dito, analisaremos dois poemas «transgressivos», pois, ao que tudo indica, parecem ser fruto de uma mistura de gêneros. As questões que nortearam o desenrolar do artigo são as seguintes: (i) como disciplina integrada à Lingüística, a Análise do Discurso é "transgressiva"? (ii) em relação à transgressão genérica, deve-se considerar que ela é fruto de uma mistura de gêneros ou então que ela resulta de uma ação, ao mesmo tempo lúdica e subversiva, ação esta que transpõe efeitos de um determinado gênero para outro?

\section{Palavras-chave}

Semiolingüística, Transgressão de gêneros, Efeitos de gênero, Faits divers. 
Análise do Discurso, ${ }^{1}$ se observada no vasto âmbito dos estudos lingüísticos e, sobretudo, se for comparada a estes, guarda em si aspectos "subversivos" e inovadores. Para melhor explicar o que foi dito, gostaríamos de fazer algumas digressões: iremos, assim, sobrevoar o período que marca a aparição da disciplina, na França, chegando até a Teoria Semiolingüistica, teoria que, ainda que guardando alguns conceitos-chave da Teoria fundadora, modificou-se bem em relação a esta, oferecendo um novo olhar sobre o objeto discursivo. ${ }^{2}$ Além da Semiolingüística, recorreremos também, ao longo do artigo, a algumas citações e a alguns conceitos elaborados pelo teórico francês Dominique Maingueneau. Só em seguida é que abordaremos dois poemas de autores brasileiros, ${ }^{3}$ buscando respaldo nas supracitadas abordagens da AD.

Tentaremos, assim, mostrar como a controvertida $\mathrm{AD}$, disciplina que vem modificar comportamentos e idéias já cristalizadas no campo da Lingüística, pode desvelar o lado lúdico e o desejo comunicativo que acompanha um tipo de texto - o literário - que até bem pouco tempo atrás era considerado como texto "tabu" ou cuja abordagem seria proibida para pesquisadores ligados aos estudos lingüísticos.

\section{Algumas considerações sobre a "entrada" efetiva da AD no campo disciplinar lingüístico}

Muito antes da aparição da $\mathrm{AD}$, o estudo do discurso já interessava a certos lingüistas, que, sem utilizarem precisamente a palavra "discurso", já deixavam entrever que esse objeto estava emergindo em um campo de reflexões intelectuais.

Um exemplo entre tantos: o de Roman Jakobson que lança sua "Teoria da Informação” no livro Essais de Linguistique Générale (1963). O teórico afirma que o homem usa a linguagem para se comunicar, compondo então seu 
famoso esquema, no qual um "emissor" dirige uma mensagem ao seu "receptor", mensagem esta envolvida pelo contexto, contato e código. Esses seis elementos dão lugar a funções lingüísticas tais como: a referencial, a emotiva, a conativa, a fática, a metalingüística e a poética.

Assim agindo, Jakobson estava criando o que hoje chamaríamos de "tipologia de discursos", isto é, uma unidade colocada em ação e assumida por um sujeito; naturalmente, esse primeiro esboço de uma teoria comunicativa foi amplamente utilizado e remodelado por outros lingüistas mais perto de nós. Citemos o caso de Catherine Kerbrat-Orecchioni, que, em seu livro L'Énonciation. De la subjectivité dans le langage (1980) reatualiza o esquema de Jakobson: tanto o emissor ao enviar a mensagem quanto o receptor ao recebê-la usam suas competências lingüísticas e paralingüísticas (ou seja, o gestual, o expressivo), assim como suas competências ideológicas e culturais. Por outro lado, no envio e recebimento da mensagem, há que considerar as determinações psicológicas que geraram esse ato comunicativo e não outro qualquer. De certo modo, tudo isso é imposto e/ou limitado pelos universos discursivos do locutor e do seu alocutário.

Se pensarmos, porém, no esquema enunciativo da comunicação de Charaudeau (1983), sobre o qual falaremos mais adiante, veremos que o citado teórico conseguiu tornar mais aguçada ou sofisticada ${ }^{4}$ a teoria da comunicação entre os diferentes sujeitos da linguagem.

Voltemos a Jakobson. Em 1962, ele publicou, de parceria com Claude Lévy-Strauss, uma análise do poema Les Chats, de Baudelaire: ${ }^{5}$ tal trabalho merece ser destacado por sua inovadora tentativa de aplicação de uma análise lingüística ao texto literário, análise esta em que já aparecem questões de uma lingüística discursiva que poderíamos chamar de "atual" ou moderna ...

Finalmente, saindo do que gostamos de chamar "pré-história" da AD, lembramos também que Jakobson já havia escrito suas reflexões sobre a questão discursiva em 1957, em um artigo que seria depois anexado aos seus Essais e no qual citava Volochinov/Bakhtin (autor ou autores que ainda não haviam sido traduzidos no mundo ocidental, na época). Nesse artigo, Jakobson enfatiza a articulação dos sujeitos (enunciador/enunciatários) aos discursos que esses constroem e o faz através de uma visão bastante interessante para a época, pois ela anuncia de certo modo a futura AD.

Queremos enfatizar que destacamos a figura de Jakobson como "prédiscursivo" por considerá-lo um teórico "transgressivo", a seu modo, no sentido de ter revolucionado ou ousado abrir novos caminhos, difundir novas idéias em 
um campo que poderia ter-se estagnado ou ser esquecido sem a caracterização que ele deu às funções comunicativas do discurso.

Entretanto, não podemos deixar de incluir os nomes de Bakhtin e Benveniste na panorâmica "volta às origens"6 proposta neste artigo. As teorias do primeiro são hoje largamente conhecidas por todos que se interessam não só pela $\mathrm{AD}$, mas também pela Lingüística Aplicada e pela Teoria Literária, em geral. Entre todas suas qualidades de pesquisador, Bakhtin pode ser considerado como um analista "de discursos", avant la lettre, antes mesmo que a AD tivesse sido conceituada ou nomeada. Quanto a Benveniste, suas idéias sobre a subjetividade da linguagem revolucionaram o pensamento lingüístico e se adequaram de forma perfeita às teorias analítico-discursivas com as quais temos trabalhado, ou seja, as desenvolvidas por Charaudeau e Maingueneau.

Encerremos então esse "passeio" pelos "pré-discursivos", apoiando-nos em algumas considerações de Patrick Charaudeau (2005, p. 28).

Novas noções como enunciação, corpus de textos (e não somente frases), contextos, condições de produção permitiram aos estudos lingüísticos descobrir e determinar um novo campo de análise da linguagem que não mais enviava à língua, ao estudo dos sistemas da língua, mas ao discurso, isto é, aos atos de linguagem que circulam no mundo social e que são testemunhas dos universos de pensamento e dos valores que se impõem em um dado tempo histórico. (Trad. nossa)

Essas considerações podem servir de ilustração para a trajetória que conduz à passagem "revolucionária" dos estudos da língua aos estudos do discurso.

Tal passagem parece-nos "subversiva", 7 como o são muitas outras passagens ou mudanças no âmbito da pesquisa lingüística, diante de disciplinas que tinham já seu status garantido, tais como a fonética, a fonologia, a gramática gerativa entre outras. A reviravolta em questão acontece por volta dos anos 60 do século XX, quando da aparição da teoria criada por um grupo de pesquisadores que se propôs estudar o discurso, no cenário francês. Foi Michel Pêcheux, filósofo de formação, pesquisador brilhante e carismático, quem reuniu em torno de si o grupo que criou a escola que é hoje conhecida por alguns de nós, analistas do discurso de tendência francesa, pela sigla "ADF", ou seja, "Análise do Discurso Francesa". Na França, esta escola é chamada de École française d'Analyse 
$d u$ Discours. Não é nosso objetivo discorrer longamente sobre essa teoria fundadora, no sentido amplo da palavra; vamos apenas nos limitar a apresentar alguns dos motivos que levaram a sua aparição.

Um dos objetivos da ADF era o de desvendar a manipulação ideológica presente nos discursos políticos da direita francesa: trata-se de uma análise que sempre privilegiou o poder da palavra, a sua influência manipuladora, no caso. Em outras palavras, essa teoria, como nos expõe Maingueneau no Dictionnaire d'Analyse du Discours (2002, p. 201) colocava no centro de suas preocupações
/.../ um estudo do discurso político feito por lingüistas e historiadores através de uma metodologia que associava a lingüística estrutural a uma "teoria da ideologia", inspirada pela releitura de Marx pelo filosofo L. Althusser e pela psicanálise de J. Lacan. Tratava-se de pensar a relação entre o ideológico e o lingüístico, evitando, ao mesmo tempo, a redução do discurso à uma analise da língua e dissolução do discursivo no ideológico. (Trad. nossa)

Sem dúvida, ao aparecer como instrumento de estudo na paisagem francesa, a $\mathrm{ADF}$, sobretudo nas décadas de 60 e 70 , provocou um abalo em estruturas fixas, tais como as que existiam no campo de estudo de uma Lingüística onde predominava, além das orientações estruturais, a lingüística gerativa. Contudo, ainda que "revolucionária", cabe lembrar que a ADF de Pêcheux buscava apoio na língua, tal como esta havia sido definida por Saussure (1906), ou seja, através dessa nova análise, o discurso poderia reformular a fala (parole), essa espécie de "resíduo filosófico" que deveria ser liberado de sua subjetividade ou individualidade. Resumindo bem, o discurso de todo ser falante seria sempre assujeitado a uma formação discursiva dominante, expressão que Pêcheux toma emprestado de outro filósofo, Michel Foucault ${ }^{8}$. A formação discursiva determina "o que pode e deve ser dito a partir de uma dada posição em uma dada conjectura" (1975).

Pertencem ou foram lançadas pela ADF, palavras ou conceitos-chave que continuam a vigorar em nossos dias, mesmo sob outras terminologias: queremos nos referir aqui ao "interdiscurso", ao "intradiscurso" e ao "pré-construído".

Como o diz Denise Maldidier (1993, p. 115) a um dado momento, a história pessoal de Pêcheux encontra-se com a História. Há uma revalorização do individual, marcada pela volta do sujeito. Isso tem repercussões na lingüística 
e na vida coletiva dos cidadãos. É bem verdade que Pêcheux acaba por deixar um lugar para o sujeito, no final de seu percurso, como pesquisador e chef de file. Mas a ADF resiste sempre ao "fantasma" da subjetividade. Transcrevemos, a seguir, as palavras com as quais Pêcheux encerra sua última comunicação:

Diante das interpretações sem limites nas quais o interpretante se coloca como um ponto absoluto [dono da verdade] /.../ vejo aí uma questão ética e política: uma questão de responsabilidade. (julho de 1983, trad. nossa) $)^{9}$

Como teoria, a ADF, com suas naturais hesitações e mudanças, pode assim abrir caminho para indagações futuras e para novas perspectivas analíticas referentes ao discurso. ${ }^{10}$

Em nossa opinião, uma das tentativas de respostas possíveis para algumas indagações que esta teoria deixou, sobretudo após o desaparecimento de seu criador, pode ter sido fornecida pela Teoria Semiolingüística, criada pelo lingüista francês Patrick Charaudeau e divulgada a partir de 1983, no livro Langages et Discours. A análise do discurso semiolingüística parece-nos ser um instrumento suscetível de analisar diferentes discursos sociais e suas variantes, de uma cultura para outra ou dentro de uma mesma cultura. Trata-se de uma análise discursiva que vê a linguagem como veículo social de comunicação. Ou, em outras palavras: Charaudeau propõe uma abordagem em $\mathrm{AD}$, que ele mesmo denomina "representacional e interpretativa" e cujo objeto de estudo pode ser definido através de hipóteses sobre a existência de representações sociodiscursivas dominantes em uma dada sociedade e nesse ou naquele grupo social desta sociedade.

Esta teoria, dita "antropofágica" por seu próprio criador, ${ }^{11}$ reúne saberes e estratégias vindas da Psicologia social, da Antropologia, da História, da Etnologia, sendo que esse coerente amálgama é amparado por uma sólida base lingüística; isso lhe fornece um instrumental teórico bem estruturado e aplicável para a análise de diferentes corpora, desde que estes sejam vistos como integrantes de discursos produzidos em uma situação de comunicação. Assim, o ser humano, como "sujeito-falante", é levado, a cada vez que tenta se comunicar (oralmente ou por escrito), a "encenar" sua forma de comunicação, adequando-a em função de um determinado auditório. Além disso, para que sua comunicação tenha sucesso, ele deve submetê-la a um processo que envolve sua 
imagem (seu ethos de sujeito comunicante) e uma certa dramatização sabiamente colocada em seus ditos ou escritos, que vão buscar sempre captar a atenção do "outro", seu destinatário. O mais simples dos atos de linguagem tal como um "Bom dia" que dirigimos a um colega é uma aventura na "selva da comunicação": serei respondido ou ignorado? Que tom meu colega usará na resposta? Enfim, meu desejo comunicativo, endereçado a este "outro", nele encontrará um eco ou não?

Nessa análise, o discurso é visto como um "jogo comunicativo", ou seja, um jogo que é "imposto" pela sociedade e suas produções linguageiras. A produção de atos de linguagem é imbuída de um desejo: "agir sobre o outro" (Charaudeau, ibid.).

Ao trabalhar com a Teoria Semiolinguiística, notamos que há uma questão recorrente, que poderia ser assim expressa: "-Na ótica dessa teoria, que tanto valoriza a comunicação entre seres sociais, são estes que constroem o discurso ou é o discurso que constrói o social?" A resposta talvez seja esta: deve-se achar um equilíbrio entre as partes. Seja como for, a reflexão sobre a questão passa pela Pragmática, pela Psicossociologia, pela Enunciação, pela Retórica/ Argumentação e, conforme o corpus abordado e os objetivos do pesquisador, pela Sócio-Ideologia, diz Charaudeau (1995, p. 110).

De todo modo, a Semiolingüística se inspirou na teoria da polifonia de Bakhtin. Expliquemos: nela, o ato de linguagem é considerado como uma produção assumida por diferentes vozes ou sujeitos. O primeiro deles é chamado sujeito-comunicante ou eu-comunicante, indivíduo com uma história e uma biografia, vivendo, falando ou agindo em uma determinada época; ora, à medida que esse sujeito decide transmitir uma mensagem qualquer ao "outro", ele "aciona" ou coloca em cena um "novo" sujeito: o eu-enunciador. Tal entidade dirige-se, em uma primeira instância, a um eu-destinatário ou sujeitodestinatário idealizado. O eu-enunciador "joga" sua mensagem no mundo, esperando que seu eu-destinatário virtual coincida com o eu-interpretante real. Temos então, segundo Charaudeau (1983), quatro sujeitos linguageiros, dois emissores, dois receptores.

Imaginem tal teoria surgindo em meio ao ambiente fechado de uma Linguiística "pura e dura" ou ainda ousando desafiar a poderosa teoria fundadora de Michel Pêcheux (e seus seguidores)... Quantos gritos de "transgressão às normas!" a Semiolingüística provocou e, diga-se de passagem, provoca ainda em certos grupos por demais fechados para perceber que uma $\mathrm{AD}$ pode e deve ser 
diferente de outra ou que o discurso não é propriedade de uma só teoria fundadora por mais incensada que ela seja. ${ }^{12}$

Para quem gosta de trabalhar com a transgressão genérica, a Semiolingüística oferece um bom instrumental teórico. A transgressão sobre a qual falamos pode ser verificada em vários tipos de textos. Por exemplo, basta abrir uma revista como Caras ou Isto é, para encontrar uma página ou outra que deixa transparecer uma certa mistura de gêneros: na publicidade, nas fotos, no próprio conteúdo dos textos...

Abandonando, porém, o vasto território da mídia, resolvemos ser ainda mais transgressivas e integrar em nosso corpus de análise discursiva ${ }^{13}$ textos vindos da Literatura; no caso específico do presente artigo, textos poéticos.

Cabe lembrar que as relações entre o texto de ficção e a análise do discurso (AD) provocam, ainda hoje, dúvidas ou discussões em certos meios onde a Literatura (com um "L" maiúsculo) sofre o peso de uma tradição cultural elitista que insiste em não aceitar nenhum tipo de abordagem que tenha suas bases em estudos lingüísticos.

No âmbito da análise do discurso - todas as teorias analítico-discursivas confundidas - é grande a variedade de corpora que são tomados como objeto de estudo, pelos diferentes pesquisadores: discursos políticos, publicitários, didáticos e, mais recentemente, discursos ligados à ficção. Podemos incluir, nestes últimos, os textos literários propriamente ditos (romances, contos, peças teatrais, poemas), como também crônicas, letras de músicas (hinos, óperas, canções populares), histórias em quadrinhos, cartuns, pinturas, filmes, entre outros. Em suma: textos que passam por um trabalho de criação artística.

Além dos "precursores" por nós citados, que se interessaram por esse tipo de discurso, podemos incluir no grupo alguns teóricos que estão mais perto de nós, como Charaudeau e Maingueneau. O primeiro, desde 1983, dedicou parte de suas análises discursivas aos efeitos de real e de ficção, tendo apresentado em seu livro Langages et discours (p. 154-166), uma interessante abordagem semiolinguística sobre o projeto de escritura de um nouveau roman, no caso, La Modification, de Michel Butor; em sua Grammaire du sens et de l'expression (1992), consagrou um capítulo ao Mode d'organisation narratif, usando vários excertos de textos literários para ilustrar seus pertinentes propósitos. Já Maingueneau produziu obras que se tornaram livros clássicos para quem se interessa pelo texto literário e sua apropriação pelas teorias do discurso, tais como: Eléments de linguistique pour le texte littéraire (1986), 
Pragmatique pour le discours littéraire (1990), Le contexte de l'oeuvre littéraire (1993), Le discours littéraire (2004) e Contre Saint-Proust (2006).

Citamos trabalhos de teóricos franceses, mas não seria justo de nossa parte esquecer outros pesquisadores brasileiros que também têm se empenhado, no Núcleo de Análise do Discurso da FALE/UFMG, em introduzir textos literários em suas pesquisas analíco-discursivas, tais como: Antônio Augusto Moreira de Faria (2001) com o capítulo "Interdiscurso, intradiscurso e leitura. O caso de Germinal", publicado em coletânea do supracitado Núcleo; Emília Mendes-Lopes (2004) com sua tese intitulada Contribuições ao estudo do conceito de ficcionalidade e de suas configurações discursivas; Renato de Mello (2005) organizador do livro Análise do discurso \& Literatura, no qual encontramos vários capítulos sobre o assunto, tais como os de Juan-Pablo Chiappara Cabrera ("El Sur: uma leitura lingüistico-discursiva de Borges"), Jeter Jaci Neves ("O Tiers em O Alquimista"), entre outros; e também alguns artigos e pesquisas que temos buscado produzir, sobre o assunto, desde $1998 .{ }^{14}$

Voltemos aos dois autores franceses supracitados. É bom lembrar que nem Charaudeau nem Maingueneau falam, de modo explicito, de "transgressão genérica", o que não os impediu de expor certas idéias que levaram alguns de seus leitores a formular tal concepção, como foi nosso caso.

Um conceito que muito tem-nos ajudado é o de "efeitos de ficção" versus "efeitos de real", que encontramos em Charaudeau (op.cit.); retomaremos a questão em pauta no quarto segmento do artigo. Por ora, tentamos apenas justificar nossa opção pelo estudo do texto ficcional ou literário, servindo-nos do instrumental teórico que certas teorias da AD nos fornecem.

Escolhemos, para ilustrar nossa exposição, um "caso especial” do citado texto: aquele que se constrói pela fusão lúdica de um gênero "nobre" (poesia) a um gênero "marginal" (fait divers). Acreditamos que algumas considerações sobre o segundo gênero se impõem: é o que veremos a seguir.

\section{O fait divers: um gênero marginal por excelência}

O fait divers é fruto de uma construção escrita, em todos os sentidos; trata-se de um documento elaborado pela palavra e pelo uso que dela é feito, girando em torno de um acontecimento bizarro ou trágico, cômico ou tragicômico. Toma-se um determinado acontecimento e a partir dele constrói-se uma encenação que chega mesmo a lembrar a da tragédia grega, em alguns relatos. ${ }^{15}$ 
Usando um tom bem "mundano", consideramos que o fait divers é uma espécie de "coquetel": ele se constrói por meio da mistura de doses bem distribuídas de efeitos de ficção "despejados" sobre efeitos de real.

O fait divers é construído pelo relato de um acontecimento verídico (historicamente falando), relato este suscetível de provocar reações de espanto ou de horror nos seus eventuais leitores. A existência desse gênero, midiático por excelência, perde-se na noite dos tempos. Eis um curioso caso: em meio à história de reis e de sua linhagem, de conquistas e perdas territoriais, foi registrada a passagem de um cometa, na famosa obra realizada na Idade Média francesa, a Tapeçaria de Bayeux. Ora, para aquele povo, em meio a suas guerras e disputas por coroas e impérios, tal acontecimento foi um fato especial; talvez por isso mereça ser considerado como um "ancestral" do moderno fait divers jornalístico; ${ }^{16}$ isso, evidentemente, se julgarmos a supracitada tapeçaria como uma espécie de "folhetim" dos acontecimentos da época...

É sempre bom lembrar que a terminologia fait divers apareceu, pela primeira vez, no Petit Journal, em 1863, em Paris.Os relatos desses acontecimentos "fora do normal cotidiano" vinham então acompanhados por uma gravura que tentava ilustrar a cena mais dramática da história. Mas, de modo geral, ofait divers se abriu para a modernidade quando o escritor Joseph Kessel fundou, em 1928, um jornal chamado Détective que, na sua origem, dava a palavra a escritores e advogados que ali comentavam casos judiciários. Lembremos também que, ainda que modificado em relação a sua versão primeira, esse jornal ainda existe!

Para o jornalista Lionel Duroy, o fait divers representa algo inesperado no domínio da informação em geral: é um acontecimento espontâneo, que não estava previsto ou, em outras palavras, uma espécie de "curto-circuito" ocorrido no curso normal da vida...

Ora, tal gênero não poderia passar despercebido aos olhos de certos autores: a conjunção de "ficção" mais "realidade" pode dar lugar a uma sedutora teatralização da narrativa, conferindo-lhe certas características lúdicas e, entre elas, a que advém do humor. Tal escritura pode então quebrar as "bases" um tanto quanto patéticas do fait divers, nele introduzindo processos de destruição e de reconstrução, ou seja, jogos subversivos que lembram os funcionamentos que dão vida às paródias.

Maingueneau (2002, p. 93) usa uma metáfora vinda do mundo das finanças, a de reaplicação (réinvestissement) para mostrar que "um texto ou um 
gênero, uma vez inscritos na memória, carregam em si um capital variável de autoridade, que pode ser avaliado de modo positivo ou negativo" (tradução nossa).

Partindo dessa idéia, podemos afirmar que o gênero fait divers é facilmente reconhecível, bem como, éclaro, o gênero poético. Cada um deles se situa em extremos opostos: o primeiro é marginal, agressivo e, freqüentemente, cruel, sádico; o segundo, geralmente, é caracterizado por uma certa harmonia ou beleza. São dois mundos distintos, mas ambos buscam despertar sensações, emoções em seus leitores; ambos são imbuídos de estratégias de captação e não hesitam, cada um a seu modo, em se servir de uma certa dramatização. E, por isso mesmo, ambos fornecem ao leitor, antes mesmo de sua leitura, um universo "pré-fabricado", uma expectativa de leitura provocada por um molde, uma forma... um gênero, em suma! No entanto, os dois gêneros, cada um com suas especificidades podem - em certos casos - se confundir. Vejamos isso mais de perto.

\section{Uma transgressiva reunião de gêneros... ou de efeitos de gêneros?}

Iremos examinar agora os dois textos que escolhemos para essa exposição, para melhor ilustrar a presença - ou, quem sabe, a "intrusão" com fins comunicativos? - do gênero fait divers no gênero poesia.

Texto (i): Réquiem

«QUEM MATOU
MILLÔR FERNANDES?»

Perguntará a manchete d'O DIA

Enquanto o assassino vai ao enterro

Cheio de alegria.

(MILLÔR FERNANDES. Poeminha Fatal. In: MILLÔR. Poemas. Porto Alegre: L\&PM Editores, 2001.p. 73)

Como podemos notar, trata-se de um poema pseudo-autobiográfico, em que o poeta não hesita em nomear o autor ou sujeito-comunicante (Millôr Fernandes), aqui transformado em personagem de uma história digna de um fait divers como os que são largamente difundidos por jornais brasileiros, tal como o supracitado $O$ Dia. O poeta atribui ao jornal em questão um lugar de destaque na historiazinha divulgada pelo poema: é $O$ Dia quem representa, de modo metafórico e irônico, a presença do fait divers. 
Há uma forte dose de ironia inserida nesse poema. Recorrendo a Berrendonner (1981, p.182-239), consideramos que esta anuncia uma ambigüidade argumentativa, revelando assim uma enunciação paradoxal, em que o locutor (ou sujeito-enunciador, para seguir a terminologia da Semiolingüística) invalida sua própria enunciação, no justo momento em que a profere. Diremos, então, que a história contada no poema, se vista como um macro ato de linguagem, comandado pelo enunciado-chave «Quem matou Millôr Fernandes?» segue esse movimento autodestrutor, movimento "escorpiônico" (DACONTI, 2002, p. 89) que não é estrangeiro ao fenômeno irônico. O poema brinca com uma frase tabu, com uma previsão maldita: "o poeta será um dia vítima de um inimigo e também "vítima" de um fait divers em um jornal que nãoé considerado de boa categoria, muito pelo contrário"! Há uma espécie de desafio no poema: ao mesmo tempo em que ele anuncia um fim trágico para quem o escreve, ele realiza uma espécie de esconjuro para tal fim. A distância com que um eventual fait divers é encarado faz com que esse perca sua força trágica e lhe dá dimensões tragicômicas. É interessante também notar que a ironia aparece pela fusão de dois campos que se opõem no curto espaço do poema: seus três primeiros versos são lúgubres e os dois últimos engraçados, pois, neles, o humor (negro) se faz ouvir, através do som da voz do assassino, mesmo se seu riso é apenas explícito, escondido atrás da palavra "alegria".

Seguindo Charaudeau (1992, p. 763), podemos aqui detectar a presença e intervenção do "autor/escritor": o pequeno poema apresenta marcas discursivas que enviam o leitor para seu projeto de escritura: sabemos, por ele, que Millôr lê ou conhece o jornal $O$ Dia, por exemplo; ou, em outras palavras: O Dia é revelado como fonte de inspiração para a composição do poema. Assim, vemos neste o que o citado lingüista chama "efeito de veracidade": o escritor é um indivíduo que representa um papel social no mundo das letras brasileiro e está mais ou menos consciente do fato de que pode estabelecer um "efeito de cumplicidade" com seu leitor. Nesse sentido, o poeminha propõe um contrato de leitura específico.

Observemos agora o segundo poema, ${ }^{17}$ aqui escolhido para objeto de uma "leitura discursiva": 
Texto (ii): Tragédia brasileira

Misael, funcionário da Fazenda, com 63 anos de idade.

Conheceu Maria Elvira na Lapa - prostituída, com sífilis, dermite nos dedos, uma aliança empenhada e os dentes em petição de miséria.

Misael tirou Maria Elvira da vida, instalou-a num sobrado no Estácio, pagou médico, dentista, manicura... Dava tudo quanto ela queria.

Quando Maria Elvira se apanhou de boca bonita, arranjou logo um namorado.

Misael não queria escândalo. Podia dar uma surra, um tiro, uma facada. Não fez nada disso : mudou de casa.

Viveram três anos assim.

Toda vez que Maria Elvira arranjava namorado, Misael mudava de casa.

Os amantes moraram no Estácio, Rocha, Catete, Rua General Pedra, Olaria, Ramos, Bom Sucesso, Vila Isabel, Rua Marquês de Sapucaí, Niterói, Encantado, Rua Clapp, outra vez no Estácio, Todos os Santos, Catumbi, Lavradio, Boca do Mato, Inválidos...

Por fim na Rua da Constituição, onde Misael, privado de sentidos e de inteligência, matou-a com seis tiros, e a polícia foi encontrá-la caída em decúbito dorsal, vestida de organdi azul.

(BANDEIRA, 1993, p. 115)

Este poema de Manuel Bandeiraé geralmente considerado como um «poema em prosa». Tudo leva a crer que ele foi inspirado ao poeta por uma notícia de jornal. Em Tragédia brasileira, a reunião de gêneros (poesia e fait divers) é diferente daquela do poema de Millôr: ela se dá em "ritmo de pastiche-paródico".

A presença da ironia é soberana em Tragédia brasileira. Tentemos desconstruí-la, para chegar a sua mise en scène no poema em tela. Seguindo o caminho analítico que a Teoria Semiolingüística nos oferece, podemos ousar imaginar que o sujeito-comunicante Bandeira colocou em cena um euenunciador ou poeta-enunciador que fez uso da seguinte estratégia: em primeiro lugar, tomou um conjunto X (sério), constituído: (i) pela apresentação dos personagens do fait divers (um funcionário público e sua mulher, uma mulher sensual, ex-prostituta); (ii) pelo jogo de contrastes estabelecido entre o personagem que representa o Bem, ou seja, os valores morais da vida em sociedade (o marido) 
e o personagem que representa o Mal, ou seja, o não-controle do desejo (a mulher). Estamos aqui diante de uma representação estereotipada "homem $v s$ mulher". O primeiro, como aquele que vem impor a ordem na desordem; a segunda, como o ser erótico por excelência, aquela que não consegue reafrear seus instintos, parecendo ter um pacto com o Diabo.

Em seguida, esse eu-poeta-enunciador somou ao conjunto X um conjunto Não-X (não-sério) onde subitamente os papéis foram invertidos: o Bem virou o Mal (o marido assassinou a esposa), o Mal virou o Bem (a esposa tornase apenas uma frágil vítima, uma espécie de romântica borboleta vestida de organdi azul...) Tal estratégia desvenda a "zombeteira" paródia do poema de Bandeira: ela se apóia, evidentemente, na ironia que causa essa revolução interna na história do casal. Assim, a escolha do sintagma "organdi azul" parece revelar o parti-pris do eu-poeta-enunciador em favor da vítima, uma certa simpatia por esse "ser de papel" marginal ou transgressivo por excelência. O estereótipo citado é jogado por terra e ali jaz em "decúbito dorsal". A inclusão dessa expressão técnica do discurso policial coopera mais ainda para que a mistura de gêneros se estabeleça.

Notamos que, tanto em Millôr quanto em Bandeira, há a presença de um bizarro sujeito-narrador-testemunha dos fatos: sujeito não-real, "ser de papel". Mas, ao contar as "histórias", através da poesia, tal sujeito faz um apelo à vida real, aos seres marginais de nossa sociedade e ao que poderia realmente ter acontecido e ser transformado em matéria para um verdadeiro fait divers ou notícia de página policial de jornal: em primeiro lugar, o assassinato sem explicação de um autor famoso no Brasil, por sua vasta produção (crônicas, caricaturas, charges, peças teatrais); em segundo lugar, o assassinato de uma ex-prostituta por seu marido, cansado de suas repetidas traições. Em termos discursivos: efeitos de real são chamados para atuar em um campo onde domina a ficção.

Patrick Charaudeau (1992, p. 698) usa a terminologia efeito de gênero para falar de casos similares aos que acabamos de citar. Segundo ele, o efeito de gênero acontece quando são usadas frases, sintagmas mais ou menos estereotipados e já conhecidos como pertencentes a um certo gênero. Eis aqui um exemplo bem corriqueiro: se usarmos "Era uma vez..." para relatar um fato verídico, estaremos introduzindo em nosso relato um efeito de ficção.

Isso nos leva a refletir: houve realmente uma transgressão de gêneros, no caso dos dois poemas transcritos? Os eu(s)-enunciadores-poetas fizeram um "mix" da escritura do gênero fait divers à escritura do gênero poesia? Ou apenas 
convocaram efeitos de real para conferir uma maior dramatização e captação do leitor? Se assim for, tanto Réquiem quanto Tragédia brasileira foram estrategicamente construídos sobre o citado efeito de gênero...

Esse raciocínio parece elucidar o problema da transgressão de gêneros. Chegamos assim à conclusão que é o gênero poético aquele que domina os dois textos, com as estratégias que lhe são próprias; porém, tal gênero convoca efeitos de outros gêneros para si.

A questão que fica é: por que agir assim, no domínio de uma escritura poética e ficcional? A resposta não é complicada: na ótica da análise do discurso, textos visam transmitir mensagens aos seus leitores; e poemas são considerados textos se examinados pela teoria em tela. Eles buscam interpelar seus sujeitosinterpretantes, como os textos midiáticos: para tanto, no presente caso, apelam para os efeitos patéticos dofait divers. Por outro lado, há que se notar que este procedimento carrega consigo um modo lúdico de escrever ou de pensar o mundo. Ha uma espécie de "jogo", jogo cruel, uma "nuvenzinha” de humor negro que flutua no ar, sobre os poemas e que pode continuar a interpelar o sujeitointerpretante mesmo após sua leitura terminada: essa "nuvenzinha" estaria ligada à representação paródica daquilo que poderia realmente ter acontecido e ter sido relatado pela mídia. Mas, ao brincar com a tragédia, os poemas a minimizam sem, no entanto, excluí-la: eis aqui, de novo, a presença do "movimento escorpiônico" da ironia.

\section{Algumas palavras para concluir}

O universo de ficção dos dois poemas examinados é marcado por uma espécie de "sobrenatural maldoso", como o diz Charaudeau (1983, p. 89), sobretudo o primeiro. Falar do mal, segundo o autor, é sempre um modo de exorcizar nossos demônios... Desse modo, nos dois poemas figura um contrato de insólito, que interpela o leitor.

Devemos ainda insistir para o fato de que o "real" encenado nos poemas é inspirado pela imprensa: a ficção propriamente dita (no caso, dupla ficção, já que ela existe no fait divers jornalístico e é recomposta no fait divers fictício) acontece na focalização (close) dada aos atores-personagens e também pela construção de uma imagem obsessiva do Mal em luta contra o Bem.

Como o diz Maingueneau (2002, p. 94) houve aqui uma "nova aplicação" ou "re-aplicação" da palavra. Mas esse réinvestissement pode ter diversos graus. 
No caso de Millôr, nota-se mais rapidamente, talvez, a presença do lúdico, próprio à paródia. No caso de Bandeira, o lúdico se apresenta em dois níveis: no do enunciado (onde vemos a inclusão do romântico “organdi azul", a divertida listagem de ruas e bairros cariocas...) e no da enunciação, enquanto criação poética prevista pelo sujeito-comunicante, tendo este optado pela "construção" de um poema "escrito à moda de..." um fait divers. Pastiche ou paródia? Eis a questão. Talvez Tragédia brasileira seja um pastiche parodiante; talvez seja uma paródia pastichante... Em todo caso, parece-nos o resultado de um belo exercício lúdico.

Notemos enfim que a inserção de acontecimentos "copiados" de um duro mundo real (crimes) colocados num mundo contado pela poesia passa por uma necessária "desdramatização" recebendo, através da palavra do eu-poetaenunciador, uma maquiagem sutil: é ela quem confere um ar menos grave e mesmo zombeteiro a tais acontecimentos. O fait divers aí aparece mais como um pied de nez dado pelos atores-personagens ao destino, num jogo "subversivo". Em outras palavras: tal transição só é possível pelo humor presente nesse tipo de escritura, que brinca com os diferentes efeitos de gênero. Com humor e ironia pode-se dizer muita coisa...

Resta-nos dizer que teorias discursivas como a Semiolingüística não deixam, afinal de contas, o sujeito-interpretante completamente "solto" e sem limites em sua interpretação, como temia Pêcheux ao falar do futuro da AD, justamente por levar em conta o Projeto de palavra que antecede toda produção linguageira...

\section{Notas}

${ }^{1}$ Doravante designada como AD.

${ }^{2}$ Como em um processo de mise en abyme, se a Teoria fundadora da Análise do Discurso, na França, já se apresentava como "transgressiva", a Teoria Semiolingüística será duplamente transgressiva em relação a esta.

${ }^{3}$ Estes também "transgressivos", em relação à poesia vista como lírica pura.

${ }^{4}$ Mas de simples decodificação/aplicação.

${ }^{5}$ Em uma entrevista, eis o que Jakobson (Cahiers Cistre, n. 5, 1978, p. 17) disse sobre tal colaboração: "Lévy-Strauss e eu acabamos por nos tornar alunos um do outro [na Ecole Libre des Hautes Etudes]. Eu assistia aos seus cursos de antropologia e ele aos meus de lingüística. Acho que ele considerou a abordagem lingüística como 
enriquecedora para a antropologia. Eu considero a lingüística como um dos domínios da antropologia cultural./.../ Essa cooperação virou em nossa vida um fator produtivo e uma das expressões espontâneas dela foi nosso trabalho comum sobre Les Chats, de Baudelaire." (Trad. nossa)

6 "Volta às origens" que, forçosamente, será injusta e incompleta, pois o espaço de um artigo nos obriga a escolher apenas alguns dentre os vários "precursores" da AD. ${ }^{7}$ As palavras "subversiva", "transgressiva" serão aqui empregadas sempre no bom sentido do termo, ou seja, como portadoras de inovações teóricas corajosas.

${ }^{8}$ Conceito este introduzido em 1971, no número 24 da revista Langages.

${ }^{9}$ Apud MALDIDIER, Denise, 1993, p. 119.

${ }^{10}$ Não podemos deixar de lembrar de que essa análise, com as devidas modificações teóricas que o tempo vai impondo, continua a ser praticada na França ou fornece ainda um referencial teórico de base; neste sentido, ver a Apresentação da Revista Langages $n^{\circ} 117$, feita por Dominique Maingueneau (1995, p. 5-11); cabe também lembrar que a teoria em pauta emigrou para outros países, como o Brasil, por exemplo.

${ }^{11}$ Em Conferências realizadas no Brasil e, mais recentemente (2006) no LASELDI de Besançon - Franche-Comté (França), bem como em discussões no CAD, laboratório francês dirigido por este pesquisador.

${ }^{12}$ Atualmente existem múltiplas abordagens discursivas e todas são válidas, segundo os objetivos daqueles que as utilizam. Citemos algumas, a título de ilustração: a Análise Crítica do Discurso, a Análise do Discurso que trabalha com a Lexicometria, a Semiótica Narrativa e Discursiva...

${ }^{13}$ Dentro da pesquisa que empreendemos sobre Gêneros Transgressivos.

${ }^{14}$ São apenas alguns casos entre tantos outros; pedimos desculpas aos autores que deixamos de citar apenas por questão de espaço e não de mérito.

${ }^{15}$ Notamos tais casos, quando da elaboração de nossa Dissertação, nos anos 80 (século XX), principalmente em faits divers relatados pela imprensa francesa e que apareciam mais sob a rubrica "Société" que sob a rubrica "Faits divers" propriamente dita; isso em revistas de renome da época, tais como Le nouvel Observateur, L'Express...

${ }^{16}$ Tal informação, bem como as veiculadas nos dois parágrafos subseqüentes foram obtidas graças a um dossier realizado por Marie-Christine Barillaud et al. (1985, p.76-88) sobre o tema fait divers.

${ }^{17}$ Utilizamos este mesmo poema, para realizar uma rápida análise comparativa entre ele e um poema francês, em 2003. 


\section{Referências Bibliográficas}

BANDEIRA, Manuel. Seleta em prosa e verso. Rio de Janeiro: José Olympio, 1993 [1971].

BARILLAUD, Marie-Christine et al. Le fait divers: une didactique de l'insensé. In: Le Français dans le Monde, n. 194, p.76-88, 1985.

BERRENDONNER, Alain. Eléments de pragmatique linguistique. Paris: Minuit, 1981.

CHARAUDEAU, Patrick. Langages et Discours. Paris: Hachette, 1983.

CHARAUDEAU, Patrick. Grammaire du sens et de l'expression. Paris: Hachette, 1992.

CHARAUDEAU, Patrick. Une analyse sémiolinguistique du discours. Langages $\mathrm{n}$. 117. Paris: Larousse, p.96-111, 1995.

CHARAUDEAU, Patrick. Le discours politique - les masques du pouvoir. Paris: Vuibert, 2005.

CHARAUDEAU, Patrick; MAINGUENEAU, Dominique. Dictionnaire d'Analyse du Discours. Paris: Seuil, 2002.

CHIAPPARA, Juan-Pablo Cabrera. El Sur: uma leitura lingüística discursiva de Borges. In: MELLO, Renato de (Org.). Análise do Discurso \& Literatura. Belo Horizonte: Segrac, 2005. p. 63-84. (Col. NAD/FALE/UFMG)

DACONTI, Geruza Corrêa. Reconstrução da racionalidade jurídica: retomadas diafônicas no discurso processual civil. 2002. Dissertação (Mestrado em Estudos Lingüísticos) - PosLin/FALE/UFMG.

FARIA, Antônio A. M. Interdiscurso, intradiscurso e leitura. O caso de Germinal. In: MARI, H. et al. (Org.). Análise do Discurso: fundamentos e práticas. Belo Horizonte: Segrac, 2001. p.241-288. (Col. NAD/FALE/UFMG)

JAKOBSON, Roman. Essais de linguistique générale. Paris: Minuit, 1963.

JAKOBSON, Roman. Cahiers Cistre, n. 5, Lausanne: Âge de l'Homme, 1978.

KERBRAT-ORECCHIONI, Catherine. L'Énonciation. De la subjectivité dans le langage. Paris: Armand Colin, 1980.

MACHADO, Ida Lucia. Les faits divers et leur application pédagogique. 1985. Dissertação (Mestrado) - USP, São Paulo.

MACHADO, Ida Lucia. Le fait divers: tragédie moderne? Rencontres - Revista do Departamento de Francês da PUC-SP, n. 6, 15-26, 1995. 
MACHADO, Ida Lucia. O charme discreto da transgressão de gêneros na poesia. In: Mari, Hugo et al. (Org.). Análise do discurso em perspectivas. Belo Horizonte: Ed. Segrac, 2003. p.83-100. (Col. NAD/FALE/UFMG)

MAINGUENEAU, Dominique. Eléments de linguistique pour le texte littéraire. Paris: Bordas, 1986.

MAINGUENEAU, Dominique. Pragmatique pour le discours littéraire. Paris: Bordas, 1990.

MAINGUENEAU, Dominique. Le contexte de l'oeuvre littéraire. Paris: Bordas, 1993.

MAINGUENEAU, Dominique. Présentation. Langages, Paris: Larousse, n. 117, p. 5-11, 1995.

MAINGUENEAU, Dominique. Captation vs Subversion. In: CHARAUDEAU, Patrick; MAINGUENEAU, Dominique (Org.). Dictionnaire d'Analyse du Discours. Paris: Seuil, 2002. p. 93.

MAINGUENEAU, Dominique. Le discours littéraire. Paris: Armand Colin, 2005.

MAINGUENEAU, Dominique. Contre Saint Proust. Paris: Belin, 2006.

MALDIDIER, Denise. L'inquiétude du discours. In: Semen, numéro 8. Besançon: Presses Univ. de Franche-Comté, 1993.

MENDES-LOPES, Emilia. Contribuições ao estudo do conceito de ficcionalidade e suas configurações discursivas. 2004. Tese (Doutorado em Estudos Lingüísticos) - PosLin/FALE/UFMG.

MELlO, Renato de (Org.). Análise do Discurso \& Literatura. Belo Horizonte: Segrac, 2005. (Col. NAD/FALE/UFMG)

MILLÔR FERNANDES. Poemas. Porto Alegre: L\&PM Pocket, 2001.

NEVES, Jeter Jaci. O Tiers em O Alquimista, de Paulo Coelho. In: MELLO, Renato de (Org.). Análise do Discurso \& Literatura. Belo Horizonte: Segrac, 2005. p.85100. (Col. NAD/FALE/UFMG)

PÊCHEUX, Michel. Les vérités de La Palice. Linguistique, Sémantique, Philosophie. Paris: Maspero, 1975. 